\title{
An exploration of fresh expressions as missional church: Some practical-theological perspectives
}

NGTT DEEL 55, NR 3 \& 4, 2014

\author{
Nell, Ian A \\ Stellenbosch University \\ Grobler, Rudolph \\ Stellenbosch University
}

\section{ABSTRACT}

The mainline churches in Europe and North America are on the decline. Mainline denominations are struggling to reach the unchurched in a fast changing world. New ways of being church and doing mission are on the rise all over the world. Fresh Expressions is one of the ways that mainline congregations (especially in the Anglican Church in England) are seeking to be missional in contemporary culture. This study seeks to give a practical theological analysis of Fresh Expressions through some empirical and reflective work. A research team visited some Fresh Expressions initiatives in London and found a pattern of practice that can be described as inviting, accepting and challenging. Secondly, the researchers explore these findings by using a perspective from New Testament ethics, evaluating Fresh Expressions through the lenses of community, cross and new creation. Lastly, a synthesis of the data is made and the researchers also look at possible applications of some aspects of the movement within mainline denominations in South Africa.

\section{KEY WORDS}

Missional Church, Fresh Expressions, New Testament, Practical Theology, Richard Hays

\section{TREFWOORDE}

Missionale kerk, Fresh Expressions, Nuwe Testament, Praktiese Teologie, Richard Hays 
NELL, IAN A GROBLER, RUDOLPH

\section{CONTACT DETAILS}

Prof Ian Nell

Ministry \& Congregational Studies, Faculty of Theology, Stellenbosch University

Privaatsak X1, Matieland, Suid-Afrika, 7602

ianell@sun.ac.za

Rudolph Grobler

Faculty of Theology, Stellenbosch University

Privaatsak X1, Matieland, Suid-Afrika, 7602

wolliegrobler@gmail.com 


\section{INTRODUCTION}

The institutional Church of our day is experiencing many challenges in trying to connect to people in a culture that is characterised by post-modernism, postdenominationalism as well as a post-Christian mind-set (Doornenbal 2012). The result of this is that there is always a search for new ways of expressing being the church that explore methods in which to connect with people in a fast-changing world. As it becomes clearer that the traditional church ministry is not attractive to many people anymore, the need for new ways of being church is becoming very urgent (Smit 2007:594).

In addition to this, new methods of church planting are being researched and implemented. ${ }^{1}$ New churches ought be planted in a specific context and not cloned from another context according to Bishop Graham Cray (2009:xii), one of the leaders in the Fresh Expressions movement. These new communities of faith must also endeavour to stay faithful to the calling of Christ in means that could be described as counter-cultural. They need to incarnate into the dominant culture of the day, but must not conform to that culture. An ever-present danger in new expressions of being church is that the church can easily become an expression of the dominant culture rather than an expression of the gospel of Jesus Christ.

Since the 1990s various church groups in different countries have more intentionally started to adapt themselves to the changing culture. These churches are dynamic, contextual and missionally-oriented. This movement within the church goes by many names, including Fresh Expressions, mission-shaped churches, emerging missional churches, emerging churches or missional churches (Doornenbal 2012:25). These different terms cannot be simply equated with each other, but they all have a specific focus on church-to-culture and thus church-to-mission.

Fresh Expressions has come to the foreground since the publication of Missionshaped Church, a ground-breaking report from the Church of England (Percy 2010:317). Fresh Expressions succeeds in many ways to adapt to the cultural context of our day and to be missional. It also succeeds in planting new congregations. There

1 In the recent document of the World Council of Churches (2013) with the title Together towards life, the authors devote a whole section on "Local congregations: New initiatives" http://cwmission.org/missiontoolkit/wp-content/uploads/2013/12/WCC-Statementon-Mission-Evangelism.pdf. In this section they write: “Today's changed world calls for local congregations to take new initiatives. For example, in the secularizing global North, new forms of contextual mission such as "new monasticism," "emerging church," and "fresh expressions," have redefined and revitalized churches"(2013:27). 
is, however, also criticism of its theology and methods. ${ }^{2}$ It is therefore necessary to evaluate such a movement from a practical-theological viewpoint before its methods can simply be implemented in different cultural contexts, for example in South Africa.

\section{TERMINOLOGY}

According to the organisation's official website a Fresh Expression of Christian gathering and worship is: “ ... a new form of church for a fast-changing world that serves those outside the existing church, listens to people and enters their culture, makes discipleship a priority and intentionally forms Christian community" (Fresh Expressions 2012:43).

A Fresh Expression is therefore:

- Missional (it serves those outside the church);

- Contextual (it listens to people and enters their culture);

- Formational (it makes discipleship a priority); and

- Ecclesial (it forms church).

Church planting refers to the creation of new communities of the Christian faith as part of the mission of God to give expression to the Missio Dei in every geographic and cultural context (Cray 2009). This study is done within the field of Practical Theology and the researchers therefore approach the study as a theological discipline. It is that branch of Christian theology that seeks to construct actionguiding theories of Christian praxis in particular social contexts (Root 2009: 64). The practical theologian is acting as an interpretive guide trying to discern the Godhuman interaction in different areas of actions (Osmer 2008).

An important recent development in this regard is the term that Archbiship Rowan Williams coined "the mixed economy" in which he is pleading for contextual churches to be birthed in this way. The "mixed economy" is looking for ways in which fresh expressions of church can exist "alongside inherited forms in relationships of mutual respect and support. The mixed economy contains the idea of bringing

2 For a very balanced critique, especially on the "mixed economy" approach to Fresh Expressions, see the thought provoking discussion of Moynagh (2012:434-435) in which he discusses three types of critique under the headings of prophets, purists and pragmatists - each with their own questions concerning the relationship between these new forms of church and denominational and other structures. 
Christian communities to birth in different ways for different people, but as far as possible within the existing denominations and churches"(Moynagh 2012:432).

\section{RESEARCH QUESTION}

In the light of the introductory remarks and some terminological clarification, the research question could be formulated in the following way:

What can one learn from Fresh Expressions as a movement seeking appropriate forms of Christian gathering and worship in a post-

denominationalism as well as in a post-Christian context from a practical theological perspective?

To answer the question we will first look at the basic theology and praxis of some forms of Fresh Expressions in action. The empirical input will be followed by examining the results through the lenses of New Testament ethics, specifically making use of the work of Richard Hays. In the final part attention will be paid to the way in which Fresh Expression might find some possible applications within socalled mainline congregations in South Africa.

\section{METHODOLOGY}

With regards to the empirical research, various qualitative data collection techniques were used, inter alia unstructured and semi-structured individual interviews, focus groups and participatory observations. One researcher (Grobler) was part of a team from Communitas ${ }^{3}$ in Stellenbosch that visited Fresh Expressions in London from 12-19 April 2013. During this time they visited and observed three Fresh Expression initiatives and had interviews with their leaders. They also visited the Fresh Expressions communications team and met up with the Fresh Expressions team during their official team meeting. The empirical data were gathered during these interviews and the notes by way of participatory observations were put on paper during the reflections of the research team.

3 Communitas is a network of committees of the Uniting Reformed Church in South Africa and the Synods of the Western, Southern and Eastern Cape of the Dutch Reformed Church helping congregations with capacity building by focusing on their calling and gifts. See its website at http://communitas.co.zal. 


\section{FIELD WORK}

The group of researchers from Communitas visited three congregations in London that are very different from each other, but all of them can be identified as Fresh Expressions of Church.

Springfield Church is located in Wallington and the minister interviewed was Will Cookson. ${ }^{4}$

- Re:Generation is located in Gidea Park and the ministers interviewed were Jamie and Ruth Poch. ${ }^{5}$

- Moot is located in central London and Ian Mobsby was the minister interviewed. ${ }^{6}$

The group attended church services at Springfield and Re:Generation on Sunday 14 April 2013. They also had interviews with the leaders and ministers from these congregations on the same day. With regards to Moot, they had an interview with Ian Mobsby at St. Mary Aldermary on Monday 15 April 2013.

\section{a) The first round of reflection}

The first thought arising from all three of the interviews was the emphasis the interviewees placed on relationships. For Springfield the main question in terms of their mission is according to Cookson (2013): "How do we become a loving community?" and then he added: "When you select a team of people to plant a Fresh Expression of Church this team should consist of people who can build relationships, not people who are task-oriented." The experience of visiting Re:Generation left the group with a feeling that the people belongs to a family. The researchers had the impression that they are a true and authentic Christian community. The method they use to disciple people is also deeply relational: each member has both a mentor and an accountability partner and as soon as the member is ready becomes a mentor him- or herself. Ian Mobsby from Moot states it very clearly: "Mission in this context has got to be deeply relational" (Mobsby 2013).

These initial thoughts of the research group are supported by literature on these kind of emerging movements. According to (Boren 2010:24) and (McNeal 2011:911) many people are not so much interested in what the right set of beliefs are, they are asking what is the right way to live. To put it in a different way: "What

4 See its website at http://springfieldchurch.org.ukl. Viewed 18 January 2014.

5 See its website at http://www.regenerationchurch.co.ukl. Viewed 18 January 2014.

6 See its website at http://www.moot.uk.net/tag/emerging-church/. Viewed 18 January 2014. 
will work for me ... and will lead to the best possible life?" The test for the church today is not so much defining what we believe as being defined by how we live in community (Boren 2010:25). That is why relationships are so important. To confess God as Triune is to affirm that the eternal life of God is personal life in relationship (Migliore 2004:76). The literature suggests that people want to see the love of God in action in a real and authentic community through meaningful relationships.

\section{b) The second round of reflection}

Emerging from a second round of reflection on the interviews, three topics arose from the interviews and focus group data. This threefold structure emerged in a certain sense from the relational focus emphasised by the interviewees and can be summarised in three words: invitation, acceptance and challenge. These three words also gave some direction in answering the basic research question, namely: What can one learn from Fresh Expressions as a movement seeking appropriate forms of Christian gathering and worship other than through congregational structures?, or to put it in another way: What will an authentic, relational, Christian community look like in a consumerist, individualistic and secularised culture?

The answers that the interviews on Fresh Expressions produced are in other words that these forms of Christian gathering and worship will be inviting, they will be accepting and they will challenge people. In the next section we show in what ways these concepts were present and operative in the interview data followed by a discussion on the meaning of these concepts.

An inviting movement

The leaders at Springfield stated that they want to go deeper and wider: deeper into Jesus and wider into the community. On their website their vision is stated as: "Wherever you are on your spiritual journey we would love to welcome you" (What should I expect? 2013). ${ }^{7}$ They have a form of Fresh Expression that is called "messy church". A messy church makes use of arts and crafts to include people and invite them to participate. It is especially focused on families and is called "messy" because there is no set structure in which things happen and everyone is really free to participate in the way they are comfortable.

The Springfield leaders strongly focus on being hospitable and welcoming towards everyone that show up at messy church. The movement is having a strong impact on families that did not previously attend church. Care is taken by the leaders to steer clear of "church language and customs" that might alienate people. A messy church

7 See its website at http://springfieldchurch.org.uk/. 
is really an open and inviting space for anyone to join and from there relationships start to form. Pastor Will mentioned that it is important to evolve and adapt to change (Cookson 2013). Springfield is always trying to stay inviting to the culture by listening to people and constantly creating spaces that are open to people in their specific context.

The first thing one notices when one meets with the leaders from Re:Generation is that they seem to be really happy to see you! We visited them before the start of their service and then stayed for the worship service. It became very clear that they weren't just happy to see us, but that they were genuinely happy to see everyone who passed through their doors! They did not have a mission statement put up somewhere or a set of core values painted on the walls, but through their conduct and character everything they communicated their values: love, acceptance, hospitality.

One of the leaders commented: "We make people feel welcome and no one is pressured to become part of the congregation or mentorship program." Not only is the space they create inviting, the lives of the people beckon you to want to join them. There were many young people who passionately spoke about their relationship with God and what the church meant to them. The effect of this is that people from many different races, cultures, backgrounds and ages come to their gatherings. There is a sense of home-coming. One of their leaders, a man who struggled with drug addiction and was searching for God for a long time, knew the moment he walked into the church that he came home. They welcomed him, did not judge him and showed him a new life with a new family.

Ian Mosby from Moot stated that the church must have fluid edges with a strong core (Mobsby 2013). This means that the church should know what it believes and who it is, but it must adapt to culture and be inviting and open to people from the outside. Moot believes in creating spaces that will help people to meet God and become Christians. It is not about forcing people to change before they can become a part of the church, but rather about inviting people to experience God. They have many ways of creating these inviting and experiential spaces. They run their own cafe inside the church building where anyone can come and sit and have a drink or something to eat. Their "services" are very practical and seek to help people discover how to live.

Moot seeks to use the church-building as a common ground where people from all backgrounds and religions can meet. They offer free meditations on Mondays and Wednesdays. Their meditation groups seek to open a silent space for all who wish to participate. They invite people to come and find rest there from the hustle and bustle of everyday life. Another way Moot creates inviting spaces is by something they 
call "Serum-spiritually injected conversation". According to Moot (Serum dialogue group 2013): "Serum is a discussion about all things spiritual. It is friendly, serious and fun. We explore questions about God in an informal, open and non-prescriptive way over a drink in the pub. An initial short thought and question starts things off after which the conversation runs freely. The evening is rounded off with an opportunity to share insights and reflections." It is clear that Moot is very focused on reaching people that are totally alienated from Christianity and church. They invite people by creating spaces of acceptance where all are welcome. They communicate in such a way that what they say resonates with people in a consumerist culture.

Upon further reflection on these observations one may say that many people don't feel welcome in church. People experience a great sense of awkwardness and inaccessibility (Keifert 1992:x). In many cases it is as if there are great barriers that keep people from truly feeling welcome. In addition to this people from outside the "church culture" don't know how the church works. For example: the liturgy that is followed and the type of language that is used tend to exclude outsiders and leave people alienated from God and others. It is as if people have two bridges to cross in church life: the bridge to discipleship and the bridge to a new church culture.

The Triune God is a God of grace and inclusion that invites people into His presence to journey with Him. The mission of the church is to participate in the reconciling love of the triune God who reaches out to a fallen world through Jesus Christ in the power of the Holy Spirit (Migliore 2004:265). Hospitality plays a big role in showing strangers that you care about them and you want to welcome them into your space. Inviting also includes being church in the world and not just trying to attract the world to your building. It is a genuine way of being open to people and including them not only on Sundays, but on every day of the week.

\section{An accepting movement}

Springfield works really hard to be a loving and accepting community. They want to move out into the community and make a difference by building relationships and serving people. In order to be accepting the leaders believe in a humble and listening posture - to God and to others. When we visited the morning service we were struck by the diversity of people. Pastor Will made a point of greeting new people and talking to them. There are no hidden agendas and no efforts to make someone a part of "your congregation", but rather an acceptance and posture of love towards anyone who enters into their community. To show their attitude of acceptance Springfield, as mentioned, started a "messy church" and a "cafe church". The purpose of these movements was to be open to people who previously did not feel comfortable in a traditional church worship service. They meet people "where they are" and accept 
them "as they are". This results in relationships being built and people's eyes become open to God's love and acceptance.

Re:Generation has a way of attracting the outcasts and "down-and-outs" of society. We met a number of people who came from a background of drug addiction. We saw midgets at the worship service. We heard stories of transvestites coming to the church for worship. The members accept every person who comes through their doors, even though it is not always easy. One of the men who came to faith had recently lost his job and was struggling with drug addiction. Some of the leaders took him in, gave him a place to stay and food to eat. Through the acceptance and care he received he could start his path of recovery, but more than that, he could start living in a relationship with Christ.

The research group experienced the feeling of a diverse family at Re:Generation. Black and white, male and female, old and young, rich and poor all lived together as an accepting community. It is not always easy, but their choice to accept instead of judge has had the effect that the boundaries that keep people out have disappeared. They actively look for opportunities to engage in relationships with strangers. They invite people to join them in worship and create a space where non-Christians will also feel loved and cared for. This accepting space acts as fertile ground where the gospel can be shared and a relationship with Christ can start.

Moot seeks to engage people who have turned their backs on religion but are still looking for spirituality. In order to accept them it is necessary to build trust and make people part of a caring community. As Ian Mobsby stated: "People want to belong before they believe" (Mobsby 2013). In a sense this is what genuine acceptance is all about: The leaders of Moot know this is not easy, because people are sometimes very rugged and stubborn. But they also realise that these are the ones the Lord came to save! The members of Moot view acceptance in the following way: "assisting people to explore and experience Christian spirituality, being a soul friend to those in and outside of the community (Mobsby 2013)." These soul friendships challenge them to accept those that are different and to include those that are not Christians. Often this will even mean accepting and loving those who are hostile towards Christians and the Christian faith. For Moot it is about gaining trust through relationships

Upon further reflection on these observations one may say that many people have negative experiences with "church people". Christians are supposed to represent Christ to the world. But, according to the research of Kinnaman and Lyons (2007), Christians are often perceived as hypocritical, insensitive, and judgmental. Some who were part of the faith community experienced hurt or judgment. Others who were not Christians had a negative experience of "church people" which had a big 
influence on their experience of Christianity. In addition to negative experiences many people feel a sense of judgment and a lack of acceptance. Although the church is called to be a loving community (to those inside and outside the church), people often feel that they are not accepted just as they are. There is a sense that you have to behave according to a certain set of rules before you can belong to the community.

A different type of acceptance is needed if the church is to be an accepting movement. This new community is a place where each one can experience true love and acceptance. The life of God is essentially self-giving love whose strength embraces vulnerability (Migliore 2004:81). The faith community should wear the marks of its Creator: grace and unconditional love and acceptance. This means that people are welcomed and loved as they are without being judged or rejected, because the compassionate love of God is stronger than sin and death (Migliore 2004:81).

\section{A challenging movement}

When we asked Springfield's leaders how they defined success their answer was very simple: "Success is defined by faithfulness. Not faithful towards your tradition, but towards Christ. It is not about being consumerist" (Cookson 2013). For them this means following Jesus wherever He leads. They actively encourage people to make a difference in the community, to build relationships and to see where God is working. Their members do not just attend church; they strive to be church in the world. They are challenged to imitate Christ. This is what faithfulness translates into, for them, the imitation of Christ. They empower people to do this through teaching, Bible study and prayer, but more so by being out in the community serving others. One of their challenging initiatives is what they call "river ministries". River ministries actively seek to make a difference in the community and focus outwards. Springfield believes that this outward focus will bring growth, not only in terms of numbers, but in terms of faithfulness: producing true imitators of Christ.

Re:Generation welcomes everyone and accepts anyone, no one is pressured to become a member or forced into anything. But when someone does decide that they want to become a leader and participate in the path of growth that the church offers, then the challenge that they provide asks a lot of time and commitment. They genuinely want to make disciples and structure themselves to achieve this. Re:Generation has a very specific strategy for leading people on the path of growth and discipleship. When you become more involved at the church there are two relationships you enter into:

- Firstly, you receive a mentor. A mentor is someone who has been a Christian for a while and can guide you from their own experience. The mentorship relationship is still built on the foundation of unconditional love and 
acceptance, but there is also a challenge to grow and become more like Christ. Mentees are encouraged to be very open and honest towards their mentors. People can share their stories and pray together. Mentors challenge their mentees, support them and guide them to greater commitment in Christ.

- The second relationship into which someone enters is an accountability partner. This is a friend with who you can share your struggles and you can pray with. It is someone who holds you accountable for your conduct and trusts you to do the same for him/her. Part of the path of growth is then to start serving: both in the congregation and in the community. People who want to become part of the leadership of the church must first spend a few months serving somewhere in the congregation.

Moot seeks to provide spaces where people can start to face the challenge of living the Christian life. If you want to be a part of Moot you have to participate. You cannot be a passive bystander. Once someone starts to participate there are three spaces that Moot offers which help people to discover Christianity and live the life of a disciple. The first space is what they call "exploring space", where people commit to certain aspirations. The second space is for deeper participation where people commit to certain spiritual practices and postures. The third space entails high involvement for people who want to dig deeper to become "new monastics" and desire greater mutual accountability.

There is a sense of moving deeper into true spirituality and deeper into community as people become more involved at Moot. Because Moot members see themselves as a "new monastic community" it involves a focus on ancient spiritual disciplines and practices. These are broken down into aspirations, postures and spiritual practices. The aspirations, postures and spiritual practices have the goal of promoting a "rhythm of life" that gives life and moves away from a life of sin. The aspirations include presence, acceptance, creativity, balance, accountability and hospitality. The postures that are adopted are characterized by openness, mindfulness, expectancy, wonder, gratitude, compassion and obedience. The spiritual practices that help one achieve this include prayer and meditation, mercy and justice, communal worship, learning, presence, mission and passionate living.

Reflection: One of the main reasons why people become alienated from church is that they do not really experience that the church is helping them to face the real challenges of life. In many ways faith becomes removed from the pressures of real life (Willard 2009:34). In several cases it is as if the church lives in a "spiritual world" that is removed from real life and people come looking for answers for how to live, but cannot find them. In addition to this, many churches have sold out to a 
consumerist mind-set. As McNeal (2011:30) puts it: "Western culture commends a self-centred, consumerist approach to the abundant life." So many churches are giving people what they want (a consumer experience), but not what they need (the life-changing gospel and path of discipleship). When salvation does not also entail transformation the true meaning of redemption is lost (Willard 2009:34).

Men and women of Christian character and discipline should be formed within the faith community who are able to resist the lifestyle characteristic of a selfcentred consumer society (Migliore 2004:271). The process of formation does not always come automatically or easily, it takes time and discipline (Willard 2009:21). Perhaps the familiar saying puts it best: "God loves you just the way you are, but $\mathrm{He}$ loves you too much to leave you this way." The church will always be in interaction with the dominant culture in society. She must be accessible to the world but not contaminated by the ways of the world. Perhaps the best way of looking at it is by seeing Christians as people living out restoration in culture (Lyons 2010:53). There are many different ways of living out this challenge and the movement we described as part of Fresh Expression help us to see the ways in which this can happen in different contexts.

\section{NEW TESTAMENT ETHICAL LENSES}

Although we undertook some reflection in the previous section we also want to turn to New Testament ethics for another round of reflection on the movements just described. We found the work of Hays (1996) very helpful as heuristic lenses in focusing on the normative question: What ought to be going on? - concerning these forms of Fresh Expressions (Osmer 2008:4). Hays (1996:2) writes in this regard: "Christians of all sorts ... have always deemed it essential that their ethical teachings and practices stand in continuity with Scripture."

Hays (1996:3-7) proposes a fourfold task for New Testament Ethics. Firstly, the descriptive task which is exegetical and is concerned with reading the text carefully; secondly, the synthetic task which aims to place the text in a canonical context and seeks to find coherence between different texts by means of using focal images; thirdly, the hermeneutical task that entails relating the text for our situation and

8 Some more recent research on the relationship between the New Testament documents and the missional nature of the churches has been undertaken by Kok (2011: 2012) in Galatians and 1 Corinthians as well as by Van Eck (2013) on the mission, identity and ethics in Mark. The authors chose Hays because his proposal for the fourfold task for New Testament ethics is covering the whole of the New Testament and not only single documents. 
lastly, the pragmatic task that seeks to find ways in which Christian communities can live out the text. In the synthetic task Hays (1996:187-206) proposes three images that give a focus to the New Testament witness, namely community, cross and new creation. These three focal images serve as the lenses through which one can reflect on the movements in Fresh Expressions with some sound backing from the New Testament.

\section{a) Community}

"The church is a countercultural community of discipleship, and this community is the primary addressee of God's imperatives" (Hays 1996:196). The New Testament is not written simply as instructions for how individuals can "get into heaven", but it focuses on God's design for forming a covenant people. God is not simply interested in individuals "on their own", but wants to transform humanity collectively. The entire trajectory of Scripture points to God calling out a people to embody His salvation and using these people to embody this salvation to the world. The church community, in its corporate life as the body of Christ, is meant to embody an alternative order that stands as a sign of God's redemptive purposes in the world (Hays 1996:196). In this sense Hays argues that "community" is not merely a nice concept, but it points to the social manifestation of the people of God. Everything the individual does as a member of the church should be rooted in the identity of the community.

Reflecting on the possible strengths of the movements described in Fresh Expressions concerning community we see that all of the movements the research group visited, showed a strong focus on relationships. The question would now be what the quality of these relationships is? Being relational does not necessarily mean being communal. In looking deeper at the way the relationships take shape it does appear that there is indeed something deeper. People are not simply a number on a list, but are connected with someone in the community and so become a part of that community. Friends invite other friends and networks of relationships come into existence.

Reflecting on possible threats to the community experience, can be what Beck (2002:11) sees as a form of 'institutionalized individualism" so prevalent in Western societies. This means that individuals are confronted on many levels with the following challenge: you may and you must lead your own independent life, outside the old bonds of family, tribe, religion, origin and class; and you must do this within the new guidelines and rules which the state, the job market, the bureaucracy etc. lay down. This individualism ultimately means that "I am myself by myself". It breaks bonds with the community and tries to seek the good of the self by the self. In 
other words, even though Fresh Expressions aim to create authentic community, the danger of individualism is always lurking. So it might mean that the break with traditional modes of church stems out of dissatisfaction with all things organised and communal.

Therefor some scholars such as Percy (2010:327) are of the opinion that Fresh Expressions are symptomatic of contemporary culture, which has typically adopted the rhetoric of "new", "alternative" and "fresh", which in turn is rooted in increasing individualism, and the inward turn to fulfilment and personal enhancement. This can have a negative impact on the Fresh Expressions movement. They are still young as communities and at some point in the future individualism might cause the members to just once again break away from "the old, institutional ways" and start something fresh.

\section{b) Cross}

"Jesus' death on a cross is the paradigm for faithfulness to God in the world." (Hays 1996:197). "The only table of fellowship in the Christian faith is the wooden table that morphs into a wooden cross" (McKnight 2010:21). Love is often seen as the basic Christian command and ethic, but for Hays (1996:202) love is not sufficient, because it is not an image in itself but rather an interpretation of an image. The term love can be easily manipulated to mean whatever we want it to mean. It can also exclude some and include others.

What the New Testament means by love is embodied in the cross (Hays 1996:202). This means that the community of faith must be formed by the paradigm of the cross. Jesus' death is an act of self-giving love and the community is called to take up the cross and follow Him by imitating His example (Hays 1996:197). On a practical level this means that the way the Christian community must live is defined by obedience, self-giving and sacrifice - this is the essence of imitating Christ (Hays 1996:197). The church is a radical community, shaped by what Jesus did on the cross. This means that people are to be loved unconditionally and forgiven and served, because this is what Christ has done for us.

Reflecting on the possible strengths of Fresh Expressions in terms of the cross, we see that the way in which the movements focus on accepting people unconditionally without judgment and welcoming them with hospitality into communion, reflects the way the cross shaped these movements. These Fresh Expressions movements show love to people, not because they act or look a certain way, but in spite of all these things. Strangers are welcomed, outcasts are included, and sinners are accepted. These are some of the practical ways the gospel is lived through love in 
Fresh Expressions. One thing that stood out was the way that the love of the cross was lived out towards people who will never feel at home in a "traditional" form of church. The radical message of the cross is lived out by a radical community of love.

Reflecting on possible threats to the paradigm of the cross is the ever present reality of moralism. "The most common way that we in the Christian community have of avoiding or marginalizing Jesus' death is by constructing a way of life that is safe and secure and guilt-free" (Peterson 2008:15). Moralism is a way of living that separates salvation from what Jesus has done for us on the cross. It is a focus on outward behaviour and correct conduct that tries to give us control and puts the cross on the margin. It imposes right behaviour on oneself and others (Peterson 2008:16).

The moment that the cross becomes an example of what we should do rather than a sign of what Christ has done, then any movement runs into trouble. Sometimes people respond negatively to the cross and then Christians try to sugar-coat the message of suffering and the way God brings salvation. Moralism is just one way in which people reject God's gift and try to make their own way. Peterson (2008:20) says that moralism works from the assumption of human ability and arranges life in such a way that my good behaviour will guarantee protection from punishment or disaster. In moralism there is no place for vulnerability. Although the research group was not present long enough amongst the movements they visited, moralism is always a danger for nullifying the work on the cross.

\section{c) New creation}

"The Church embodies the power of the resurrection in the midst of a not-yetredeemed world" (Hays 1996:198). "Therefore, if anyone is in Christ, the new creation has come: The old has gone, the new is here!" (2 Cor 5:17, NIV). In the present time, the new creation already appears, but only proleptically; we now hang in the suspense between Jesus' resurrection and his parousia (Hays 1996:198). As Christians we live in the tension between the "already" and the "not-yet". Sinners are justified before God, but sinners are also sanctified to live new lives in the present age. Disciples of Jesus have the odd capacity for simultaneous joy amidst suffering and impatience with things as they are (Hays 1996:198).

Living with a new identity in Christ, we know that the new creation is already appearing. In this image of a new creation we are challenged to live a new life, but also reminded that the old is still with us. As Paul said: "Now we see only in part." But we see more than we previously did! We live with more meaning than was possible before the cross and the resurrection. Hays (1996:198) summarises this tension: 
"The New Testament's eschatology creates a critical framework that pronounces judgment upon our complacency as well as upon our presumptuous despair."

Reflecting on the possible strengths we saw that the Fresh Expressions movement do challenge people to a live different kind of life. They engage people on a level that seeks to go deeper into authentic life. Sinners are forgiven and accepted and invited into the community, but it doesn't stop there - they are also trying to discern what it means to be faithful to God in everyday life. There is not only one way of doing this, but what is important is that something intentional should be done. Salvation is not simply about where we go when we die, but it is all about the life we live now, in Christ. "It is good to know that when I die all will be well, but is there any good news for life?” (Willard 1997:12).

The focus on spiritual disciplines in these movements embodies this commitment. One thing that stood out was the focus on prayer. Prayer is not just emphasised in services and on Sundays, but people were taught how to pray so that they can focus on God and grow in their faith. Moot especially had a focus on ancient spiritual disciplines to bring people into a rhythm of life that is in touch with God. This includes prayer, meditation, worship, learning, mission etc. The list can go on, but the point is not consuming religion like a product, but rather being transformed in the presence of God into the image of Christ.

In reflection on possible threats to the concept of new creation the challenge of religious consumerism is prominent: "Left to its own devices, the Fresh Expressions movement may actually be deeply collusive with consumerism ... Is there not a danger of weaning a generation of spiritual consumers who are resistant to religious demands?" (Percy 2010:326-329). We must take seriously the charge that one of the effects of a consumer society is that everything becomes a potential commodity, even religion (Himes 2007:143). This then means that religion becomes just another object that I place in my shopping cart, designed to fulfil my every need. Seen this way people become focused on "what they want" from the church and the impact of the life-transforming gospel is lost in their lives. They become spiritual couch potatoes, flipping through religious channels until the most entertaining one grabs their attention.

As Himes (2007:143) notes, consumer culture is not necessarily a deformation of belief, but rather a particular way of engaging religious beliefs that divorces it from practice. This is exactly where the danger for the church comes in: when the goal of religion becomes the consumption of "religious goods", then growth in discipleship no longer takes place, because the consumption becomes a goal in itself. This fosters what Willard (2009b) calls "vampire Christians", who only want a little blood for their sins, but nothing more to do with Jesus until heaven. 
The three focal images of community, cross and new creation (Hays 1996) may help us to gain some clarity, through the light radiating from the New Testament, on the movements described as part of Fresh Expressions. These images also provide the heuristic devices for discerning what the possible strengths and weaknesses of these movements are. We will conclude with some observations in this regard.

\section{FRESH EXPRESSIONS IN MAINLINE CONGREGATIONS IN SOUTH AFRICA}

De Roest (2008:251-271) wrote a chapter on "ecclesiologies at the margin" in the Routledge Companion to the Christian Church. He defines these marginal ecclesiologies in the following way: "Marginal ecclesiologies is a non-judgmental term used to describe the ecclesiologies of ecclesial communities which have arisen out of, or are located on, the margins of the mainstream (or 'traditional') churches." He goes on to show that these communities can have a remarkable influence upon their respective contexts because the edge is many times a space for innovation. One of the groups he discusses is the "emerging church" to which Fresh Expressions belong.

According to De Roest (2008:261-263) the emerging church does have a number of common characteristics of which the first is that it originated mainly in Western Europe and North America and is variously described as a movement, a process or even a mind-set. It points to something dynamic, flexible and creative, starting many times without central planning. This movement sees the church going out to others, breaking the boundaries and forms part of an outward drive. The hope is always for new processes of community-formation with people in their own context and therefore it is dynamic, full of change and fluid. Many times it contains an antiinstitutional sentiment with a lot of flexibility and a postmodern mentality. The movement wants to encourage belonging before believing and is heavily influenced by the missio Dei concept.

One can see in what ways these characteristics as described by De Roest are in line with the description of Fresh Expressions at the beginning of this contribution, namely that the movement is:

- Missional (it serves those outside the church);

- Contextual (it listens to people and enters their culture);

- Formational (it makes discipleship a priority); and

- Ecclesial (it forms church). 
Fresh Expressions as part of the emerging church movement came to South Africa via the Anglican Church and several visits of Bishop Graham Cray from England. During the past three years the Dutch Reformed Church and the Uniting Reformed Church in South Africa invited Bishop Cray on more than one occasion to explain the essence of the movement and to train some church leaders through workshops. This contact led to the visit of four researchers from Communitas to Fresh Expressions in England during April 2013.

In an official agreement between Fresh Expressions and the DRC and URCSA the literature and training manuals were officially adopted and quite a number of clergy and lay people have been trained by making use of the material. At the moment it also forms part of the programme of the Seminary located at the Faculty of Theology in Stellenbosch, who is responsible for the faith formation of the DRC and URCSA students preparing for ministry. The way in which these efforts will develop in mainline denominations in SA remain to be seen. The fact of the matter is that there is a lot of energy for the revitalising of the church.

Maybe the most important contribution from the Fresh Expressions movement for the mainline congregations in South African could be the concept of the "mixed economy" already referred to. Moynagh (2012:435-441) uses five theological lenses as a basis for the mixed economy. The first is a Trinitarian perspective looking at the way the Trinity models unity and diversity; the second is a creation perspective concentrating on the way that God built unity and diversity into creation, including humanity; the third is a New Testament perspective showing how the centre and the edge were in relationship with each other; the fourth is a sacramental perspective where the unity and diversity that is celebrated in baptism and Holy Communion are a sign to the world and the last is a prophetic perspective where conflict in the church can be seen as part of the process of discernment.

\section{CONCLUSION}

We want to end this study with a quote from Percy (2010:331) who offers some wise guidance on the road ahead: "The challenge for the church will, I suspect, lie in maintaining the extensive, utility and parochial forms of mission that go on each day, and are often unsung; yet also allowing the effervescence of new movements (usually associational in outlook, market-driven, intensive, etc.) that will continue to both challenge and feed the institution."

One of the biggest challenges that the church is facing today is the constant temptation to outsource its mission. We do have to keep in mind that it is not only fresh expressions of being the church that is to be missional, contextual, ecclesial 
and formational, but all forms of church are called to this. Already in 1926 the missiologist Roland Allen (2008:18) forecasted the tragedy of outsourcing mission from the life of the church:

In the beginning the Church was a missionary society: it added to its numbers mainly by the life and speech of its members attracting to it those who were outside ... Today members of the church are scattered all over the world, but they do not carry the church with them in their own persons, they were not organized, they very often do not desire the conversion of those among whom they live, the do not welcome them into the Church. The Church, as a Church, is not a missionary society enlarging its borders by multiplying local churches; so societies are formed within it to do its work for it.

Perhaps what is happening with Fresh Expressions is a form of escapism. So-called mainline churches that are struggling with their missional calling are escaping from this struggle through Fresh Expressions. In this way Fresh Expressions are becoming the "societies formed within it to do its work for it" (Allen 2008:18). On the other hand, such Fresh Expressions themselves may be a form of escape: escape from tradition, oldness and the cost of day to day ordinary discipleship. Escape from the others, who are so different from us. The gospel does not allow this escapism. The gospel forms us into a community which proclaims the gospel, but also a community that bridges the gaps between our differences. There is much to learn from Fresh Expressions, but the church must always be church, whether it is fresh or traditional.

\section{REFERENCES}

Allen, R 2008. The spontaneous expansion of the church. Cambridge, UK: Lutterworth.

Beck, U 2002. Individualization: Institutionalized individualism and its social and political consequences. London: SAGE.

Boren, MS 2010. Missional Small Groups (Allelon Missional Series): Becoming a Community That Makes a Difference in the World. Grand Rapids: Baker Books.

Cray, G 2009. Mission-shaped Church: Church Planting and Fresh Expressions of Church in a Changing Context. London: Church House Publishing.

De Roest, H 2008. "Ecclesiologies at the margin", in Mannion, G \& Mudge, L (eds.). The Routledge Companion to the Christian Church. New York and London: Routledge. 
Doornenbal, RJA 2012. Crossroads: An Exploration of the Emerging-Missional Conversation with a Special Focus on Missional Leadership and Its Challenges for Theological Education. Delft: Eberon Academic.

Hays, R 1996. Moral Vision of the New Testament: A Contemporary Introduction To New Testament Ethics. London \& New York: Bloomsbury Academic.

Keifert, P 1992. Welcoming the Stranger: A Public Theology of Worship and Evangelism. Augsburg Fortress: Minneapolis.

Kinnaman, D \& Lyons, G 2007. unChristian: What a New Generation Really Thinks about Christianity ... and Why It Matters. Grand Rapids: Baker Books.

Kok, J 2011. Mission and ethics in Galatians. HTS, 67(1).

Kok, J 2012. Mission and Ethics in 1 Corinthians: Reconciliation, corporate solidarity and other-regard as missionary strategy in Paul. HTS, 68(1).

Lyons, G 2010. The Next Christians: Seven Ways You Can Live the Gospel and Restore the World. New York: Random House LLC.

McKnight, S 2010. A Community Called Atonement: Living Theology. Nashville: Abingdon Press.

McNeal, R 2011. Missional Communities: The Rise of the Post-Congregational Church. San Francisco: John Wiley \& Sons.

Migliore, DL 2004. Faith Seeking Understanding: An Introduction to Christian Theology. Grand Rapids: Eerdmans.

Moynagh, M 2012. Church for Every Context: An Introduction to Theology and Practice. SCM Press: London.

Osmer, RR 2008. Practical theology: An introduction. Grand Rapids: Eerdmans.

Percy, M 2010. Shaping the Church: The Promise of Implicit Theology. Nashville: Ashgate.

Peterson, EH 2008. Christ Plays in Ten Thousand Places: A Conversation in Spiritual Theology. Grand Rapids: Eerdmans.

Root, A 2009. Relationships Unfiltered: Help for Youth Workers, Volunteers, and Parents on Creating Authentic Relationships. Grand Rapids: Zondervan. 
Smit, G 2007. "Paradigmaskuiwe in die huidige leierskapsdiskoers: Enkele praktiesteologiese oorwegings." Nederduitse Geref. Teologiese Tydskrif, 48:594603.

Van Eck, E 2013. Mission, identity and ethics in Mark: Jesus, the patron for outsiders, HTS, 69(1).

World Council of Churches, 2013. Together towards life [Online]. Available: http:/l cwmission.org/missiontoolkit/wp-content/uploads/2013/12/WCC-Statement-on-MissionEvangelism.pdf [2013, 10 November].

Willard, D 2009a. The Spirit of the Disciplines. London: Harper Collins.

Willard, D 2009b. The Divine Conspiracy. London: Harper Collins. 